\title{
Corporative Social Responsibility and Its Role in Strategy of Social-Economic Development of the Region
}

\author{
Dmitry Rodnyansky (Ph.D., assistant) \\ Ruslan Sadyrtdinov (PhD, associate professor) \\ Elena Zagladina (assistant professor)
}

Kazan (Volga region) Federal University, Kremlevskaya str., Kazan, 420008, Russia

Email: drodnyansky@gmail.com

Doi:10.5901/mjss.2014.v5n12p135

\begin{abstract}
At the present time the questions of the role of corporate social responsibility in development of regional and local communities become especially important. The article analyses the questions connected with Russian practice of socially oriented behavior of corporations in regions. The authors developed the model of interaction of the authorities, business and society in the region that allows to harmonize perspective development plans of corporations with concept of social-economic development of the region.
\end{abstract}

Keywords: Corporative social responsibility (CSR); private-public partnership; interaction of authorities and business; socially oriented behavior of Russian companies

\section{Introduction}

Performance efficiency of companies depends not only on work of top-managers, competitive strengths, internal and external environmental conditions, but on level of involvement of companies in social, economic, cultural life of the region, the level of interaction of chief executives with elite of authorities as well.

In the time of USSR all burden of social responsibility was on enterprises, they implemented the important social projects in the regions where they functioned. With transition to market economy the above mentioned responsibilities were transferred to the level of municipal and regional authorities, and great part of social programs came to end. In the beginning of XXI century with the growth of fiscal budget revenue and population welfare, the question concerning the role of business in implementation of important social projects again became relevant.

\section{Review of Literature}

Theory of corporative social responsibility (CSR) appeared overseas in the middle of the XX century and it is connected with the works of such American analysts-economists as A.Berle, G.Means and S. Sethi [1, 2]. However, initially there were significant differences in approaches of research analysts to this problem. The attempt to build up one system concept of CSR was made in the research work of A. Carroll [3].

In their works representatives of the first approach in the theory of CSR come from the statement that process of creation of value in business initially has moral aspect [4] which implies activity действие for a good cause of all parties concerned, not only economic benefit for owners of capital $[5,6]$.

In the frames of the second approach M. Friedman [7] consistently defends the statement concerning profit maximization in case of abidance of the rules of the game as the only responsibility of business. However, strategic importance of CSR for corporation which gains competitive advantage strengths at the account of adding value, is admitted [8].

In order to eliminate the above-mentioned contradictions in the theory of CSR scientists concentrated on the study of practical experience of the leading corporations in this sphere. For example, in their work Ph. Kotler and N. Lee [9] draw the conclusion of parity interests in the notion "corporative social responsibility" of public and business interests in the result of the study of questions of increase of effectiveness of social projects of companies and establishment of dialogue with groups concerned. 
In economic literature there are different points of view concerning the main factors of regional development. For example, investment into fixed basic capital of leading regional companies is considered as the main factor of attractiveness of the region $[10,11]$. The other authors think that investment into infrastructure is the fundamental factors of the development of the region [12]. Marketing approach which is based on determination of instruments emphasizing the attractiveness of the region, is of particular interest[13]. Corporative social responsibility is also and important factor for development of the region, and the level of economic activity directly influences the indicators of social-economic development [14].

\section{Discussion and Main Conclusions}

The fact that a lot of holding companies in the Russian regions were formed in the result of corporatization of state structures which existed in the times of USSR, is the essential feature of formation of these companies. It led to market monopolization, especially in the sphere of energetics, oil and gas supply, telecommunications. Such new holdings, as a rule, have dominant position on the market, extensive branch network and they control some definite sphere in the region. Thus, in the vast majority of regions of the Russian Federation exactly holding companies work in the most significant spheres. Forms of ownership are different in every region: from strong hand over enterprises of private investors, large financial industrial groups to full participation in stock capital of regional or municipal authorities.

Apart from ownership structure структуры of holding companies, their dominant position in some economic sectors of the definite region determines specific character of their work and interaction with regional authority elites. Management of such companies cannot take the aim of profit maximization as the only guide, as far as it is necessary to incorporate the business model into the strategy of social-economic development of the region. As a rule, such companies get important social projects as the charge from regional authorities. In return the local elite give some tax, administrative or organizational preferences for business. In spite of the fact that two parties take part in such interaction, already three parties get benefit from partnership: business, authorities and population of the region.

On picture 1 the research results of All-Russian Centre for Public Opinion Research opinions of the Russian concerning necessity of activation of corporative social responsibility are presented. [15]

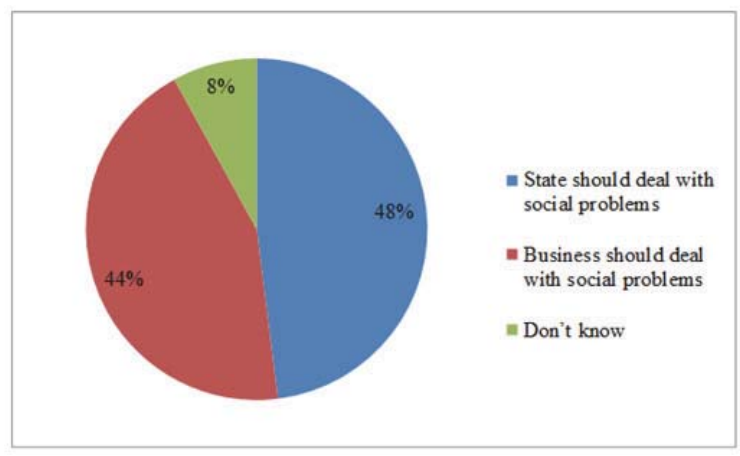

Pic. 1. Results of analysis of opinions of Russian citizens concerning necessity of activation of corporate social responsibility

As it is seen from the results, almost half of respondents wait active participation in social projects from business. It seems that such results indicate not reactionary perception of the world but understanding that medium and big business must have obligations for development of occupied territories.

At the present time only part from corporate profit tax (business tax), transport tax and property tax go into budgets of constituent entities of the Russian Federation. For this reason possibility of implementation of large infrastructural, social projects without involvement of business structures is practically reduced to zero. Year after year business takes more and more active part in public and private partnership and stops to see only charges and loss of expected profit in it. For example the company Boston College undertook the study having asked the following question to chief executives of companies: "What benefits does the company get from running a business in the definite region" [16, c.153]. Research results are presented on picture 2 . 
Pic. 2. Benefits from work on regional level
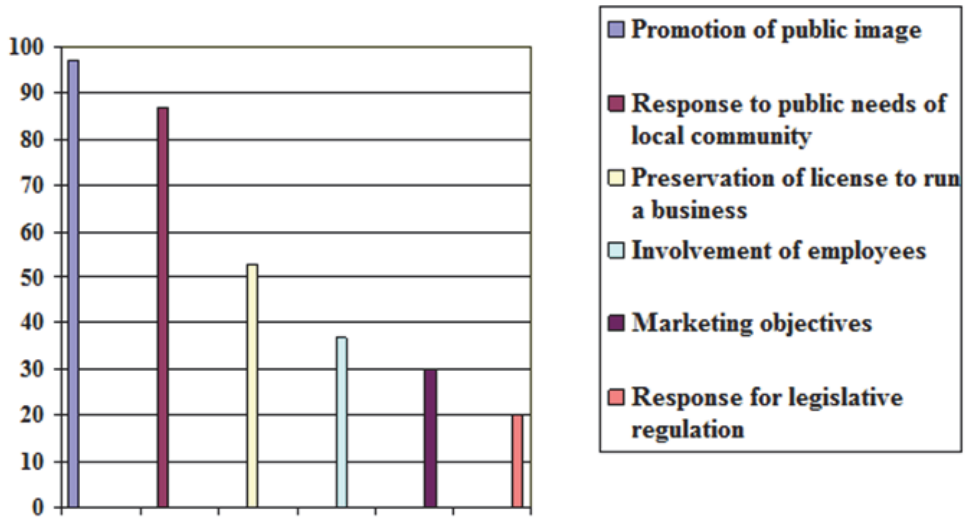

Thus, if before now corporative social responsibility was caused only by administrative actions, now chief executives of enterprises realize advantages from implementation of social and infrastructural projects.

Maximum profit making that meets the needs of stakeholders is the main principle of work of any modern company. It is evident that holding company running a business in on the regional level cannot provide the same profitability rate in all regions and municipal districts. There are remote regions, profitability of activity in which is either below the average level of the company, or is equal to zero, or its activity is unprofitable. That is why in the market conditions the company has several variants to solve the problem - to increase prices for its services or to fold operations in this region. Price increase is not always possible as far as standard of living of the population of the region can be low, and folding operations will completely leave people of the definite region without necessary goods and services. In such situations the scheme of private-public partnership is the only possible way to solve the problem. In the result of reaching agreement with companies the regional authorities meets the needs of population in communications services, energy and heat supply, fuel supply, other services in remote regions which are unattractive for business, together with holdings it also solves the problems of job creation and providing employment. Thus, authority elite performs its social functions without significant financial losses.

In its turn, population of such regions gets necessary goods at reasonable prices and is able to refuse from migration in search of work. It creates favourable social-economic and political conditions in the region; it is satisfactory to authorities, as well as to population and business. Focusing the attention of population on the role of regional holding in solving economic problems of the territory is the main task of management of the company in this situation.

From the above-mentioned partnership business gets the following preferences:

1. Tax preferences. Such actions are vindicated if enterprises realize large-scale ambitious social programs which influence the life of the whole region. At present a lot of companies support development of youth sport in the definite region, help different sport teams, clubs, organize different creative and sport events. In such cases regional authorities can reduce the rate of land tax, property tax, regional component of income tax, etc. Thus, reducing tax burden of organizations, the authorities partially compensate revenue losses of business (shortfall in income).

2. Administrative preferences. Authorities can give administrative breaks to socially oriented companies of the region. It can be expressed in fast coordination of different documentation, provision of favorable conditions of lease of land or property of the federal subject or municipal district, creation of most favorable environment (most favored nation treatment) in interaction with supervisory authorities and some other preferences. For example, a company which sells petrochemicals in remote regions, can get very good place to build fuel filling station in the regional center. It allows, first of all, to reduce costs at the expense of refusal to involve legal organizations and consulting companies, and, second, to save time and to focus much attention not on routine paper work, but directly on operating activity. At that it is necessary to strike an optimal balance and principle of efficiency giving preferences of such kind in order not to put in jeopardy competitiveness of other enterprises of the region. However, it is also necessary to encourage large regional holding companies which implement big important social, infrastructural and investment, projects.

3. Organizational preferences. Special preferences in the regions with high operational profitability can be given 
to companies which work in unattractive places of the region in order to compensate losses. It can be expressed in giving additional space for selling production and rendering of services, involvement of companies for participation in competitions of execution of public and municipal contracts, involvement of management of companies in participation in different meetings, conferences on the regional and federal levels. For example, some telecommunication companies which carry out projects of internet connection for schools, change-over to digital communication systems get preferential right for their further maintenance.

4. Reputation preferences. Constant mentioning of regional companies in connection with implementation of infrastructural, socially important projects creates their image as socially responsible enterprises aimed not only on profit maximization, but on creating conditions for economic development of the region. In modern business conditions, constantly changing environment and high competitiveness brand loyalty лояльность of customers to company plays an important role. It is very difficult to put a dollar tag from preferences of such kind, but it is evident that in the XXI century it is not possible to be successful without creation of business of a company.

Transparency and openness of elutes of authorities, as well as possibility of participation in such projects of not only close business entities, but all companies who want to participate as well, which meet standards, is an important aspect of further development of corporate social responsibility.

At present there is no any coordinating center which would allow to link up public needs with authorities and business opportunities. Social projects which are necessary to be carried out are discussed, as a rule, on governmental meetings, council boards without participation of representatives of business. In its turn, strategic plans of business development are discussed with participation of board of directors and managing executive committees in which public authorities and public officials do not always take part.

That is why the authors offer to create discussion platform which will be the mediator between authorities and business. For this it is possible to form standard permanent meeting on the basis of Chambers of Commerce and Industry of federal subjects, or on the basis of agencies and committees for the support of entrepreneurship. Such body will join interests of society, business and authorities will allow to announce the list of projects for participation of commercial entities in public and private partnership, to set out the preferences for its participants. Public institutions will be able to express their opinion concerning feasibility of such projects, to single out projects preferred for implementation and to influence social and cultural sphere of the region. Constant scheme of functioning of such discussion platform should become its important characteristic, i.e. the meeting should be held when necessary, not on periodic basis. On pic. 3 the model of interaction of business, authority and society is presented.

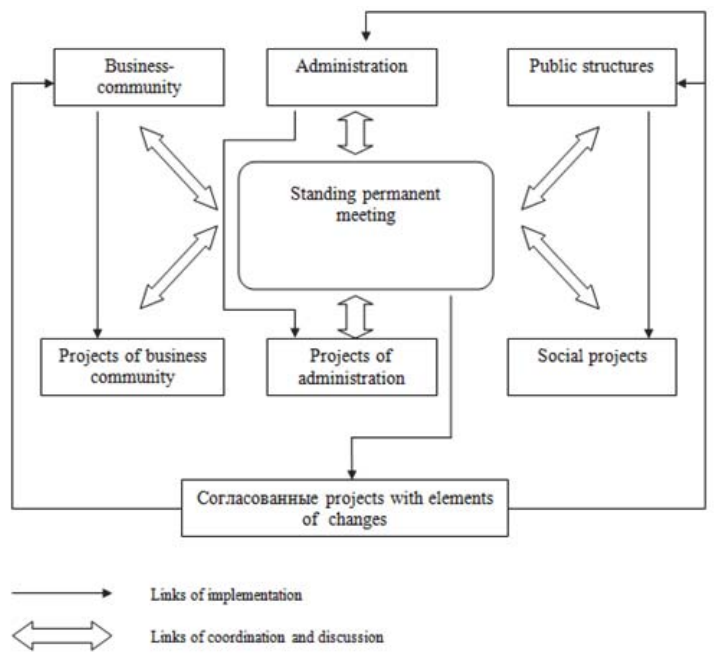

Pic. 3. Model of interaction of business, власти и общества по вопросам государственно-частного партнерства

Authority structures, organizations of business community and public institutions are subjects of this model.

This model consists of 11 stages including all stages from selection to assessment of social project implementation: 
1. Delegation of representatives from participants of the model in permanent meeting of private-public partnership.

2. Presenting the list of high priority projects by subjects of the model.

3. Offering proposals and conditions of cooperation by subjects of the model.

4. Defining project conditions, amount of social burden and preferences with account of offers of business community and public institutions by representatives of authorities.

5. Expressing opinion concerning necessity of implementation of the specified projects by public institutions, specifying requirements for business and powers.

6. Selection and adjustment of projects for implementation with account of wishes and changes introduced by subjects of permanent committee and confirmed by its executive body.

7. Selection of companies for carrying out of project on the basis of their applications.

8. Provision of a detailed plan of implementation of the part of project for every subject of the permanent meeting.

9. Implementation of projects with their concurrent monitoring.

10. Detailed report concerning project implementation indicating amount of investment and money compensated by powers at the expense of different preferences.

11. Discussion and presentation of the results of project implementation indicating benefits of parties concerned to the public.

In the result of open access for discussion of preferred projects, possibility to influence of business, as well as of public institutions concerning decision making, we can say about growth of confidence of population for businessmen, powers, strengthening of civic and political position of people. The importance of such discussion center is in the fact that holding companies, playing the significant role in economy of the region, should plan their activity without conflicting with development strategies of the territories.

\section{Conclusion}

In the result of the analysis of specific character of interaction of the elite of authorities with management of regional holding companies we came to the conclusion that profit for such enterprises is not the only criterion for choice of development strategy. Business structures - because of their dominant position on different regional markets - have to link up their perspective development plans with concept of social-economic development of the region. Proposed by the authors compromise model of public and private partnership that takes into account problems and interests of all stakeholders is the most optimal one.

\section{References}

Berle, A., Means, G., 1934. The Modern Corporation and Private Property. N.Y., pp.356

Sethi, S., 1975. Dimensions of corporate social performance: An analytical framework. California Management Review, 17 (3): 58-64.

Glebova I., Khabibrakhmanova R., Yasnitskaya Y., 2013. The analysis of the impact of the investment attractiveness factors of the region on the fixed capital investments in the economy of the Republic of Tatarstan, 2013. Middle East journal of scientific research, 10, 1498-1502.

Makarov A.N., Nazmeev E.F., Maksutina E.V., Alpatova E.S. Education reform in context of innovative development of the Russian economy. Life Science Journal 2014; 11 (6s): 372-375.

Carroll, A., 1991. The pyramid of corporate social responsibility: Toward the moral management of organizational stakeholders. Business Horizons, 34 (4): 39-48.

Bagautdinova, N., I. Gafurov, N. Kalenskaya and A. Novenkova, 2012. The Regional Development Strategy Based on Territorial Marketing (The Case of Russia). World Applied Sciences Journal, 18(Special Issue of Economics), 179-184.

Glebova I., Rodnyansky D., Sadyrtdinov R., Khabibrakhmanova R., Yasnitskaya Y. Evaluation of corporate social responsibility of Russian companies based on nonfinancial reporting.

Windsor, D., 2001. The future of corporate social responsibility. The International Journal of Organizational Analysis, 9(3), $225-256$.

Freeman, R., 1984. Strategic management: A stakeholder approach. Boston: Pitman Publishing, pp: 381.

Reich, R., 2007. Supercapitalism: The battle for democracy in an age of big business. New York: Alfred A. Knopf, pp: 311.

Friedman, M., 1970. The Social Responsibility of Business is to Increase its Profits. The New York Times Magazine, September 13: 3-4.

Porter, M., Kramer, M., 2006. Strategy \& society: The link between competitive advantage and corporate social responsibility. Harvard Business Review, 84(12), 78-92.

Kotler, Ph., Lee, N., 2005. Corporate Social Responsibility. Doing the Most Good For Your Company and Your Cause. Hoboken, NJ: Wiley, pp: 659. 
